\title{
De plicht om af te zien van het verschoningsrecht of: waar het medisch beroepsgeheim moet wijken voor de opsporing
}

Beschouwingen naar aanleiding van het arrest van de Hoge Raad d.d. 29 juni $2004^{\mathrm{I}}$

Mw. mr.drs. W.L.J.M. Duijst ${ }^{2}$ en prof. mr.T.M. Schalken ${ }^{3}$

Gezondheidsinstellingen en politie komen regelmatig met elkaar in aanraking. Wanneer dat gebeurt in het kader van de opsporing, leidt dit onvermijdelijk tot conflicten. Dat is niet verwonderlijk gezien de tegenstrijdige belangen: het belang van het medisch beroepsgeheim versus het belang van de opsporing van strafbare feiten. ${ }^{4} \mathrm{Het}$ medisch beroepsgeheim dient een tweeledig doel: het waarborgen van de privacy van de individuele patiënt en het bewaken van de toegankelijkheid van de gezondheidszorg voor iedereen. Deze doelstellingen kunnen een soepele opsporing behoorlijk voor de voeten lopen.

Opsporing in instellingen voor gezondheidszorg is in principe opsporing die verloopt volgens de regels van het Wetboek van Strafvordering (Sv). Een belangrijke bevoegdheid die politie en justitie op grond van dit wetboek is toegekend, betreft de inbeslagneming van voorwerpen met het doel de waarheid aan de dag te brengen of een wederrechtelijk verkregen voordeel aan te tonen (art. $94 \mathrm{~Sv}$ ). De omstandigheid dat de inbeslagneming plaatsvindt in een instelling voor gezondheidszorg, doet de vraag rijzen of de artikelen $96 \mathrm{a}$ en $98 \mathrm{~Sv}$, die betrekking hebben op inbeslagneming en doorzoeking bij een verschoningsgerechtigde, van toepassing zijn. Afgifte van voorwerpen die onder het verschoningsrecht vallen, is op grond van die artikelen niet verplicht (art. 96a lid $3 \mathrm{~Sv}$ ). Inbeslagneming van brieven en geschriften kan slechts met toestemming van de verschoningsgerechtigde. Bij doorzoeking dient het beroepsgeheim in acht genomen te worden. Slechts onder zeer uitzonderlijke omstandigheden -zie nader sub 6 - kunnen brieven en geschriften in beslag worden genomen.

In een recente uitspraak van de Hoge Raad d.d. 29 juni 2004 heeft de Hoge Raad de regels met betrekking tot doorzoeking en inbeslagneming bij een verschoningsgerechtigde aanzienlijk opgerekt. In deze bijdrage zullen wij die uitspraak van de Hoge Raad analyseren en van commentaar voorzien. Om twee redenen is de redenering van de Hoge Raad bijzonder. In de eerste plaats omdat dit de eerste keer is dat de Hoge Raad in medische zaken zeer bijzondere omstandigheden aanwezig acht op

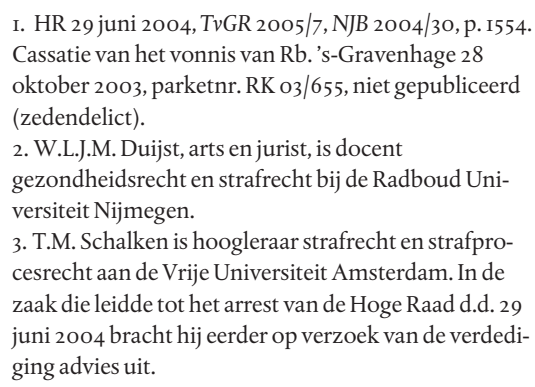

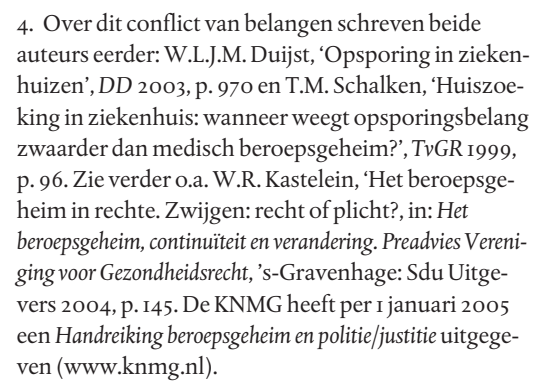


grond waarvan het belang van de opsporing dient te prevaleren boven het verschoningsrecht. In de tweede plaats vanwege de inhoudelijke argumenten die de Hoge Raad hanteert om aan het belang van de opsporing voorrang te geven boven het belang van het verschoningsrecht.

$\mathrm{Na}$ een korte weergave van de feiten behandelen wij de vragen of een zorginstelling een verschoningsrecht toekomt en wat de reikwijdte van dit recht is. Vervolgens wordt de kwestie besproken welke gegevens onder het verschoningsrecht vallen (ja voor patiëntengegevens, nee voor personeelsgegevens). Daarna komt uitvoerig de vraag aan de orde of het in het arrest van de Hoge Raad genoemde opsporingsbelang als maatschappelijk belang tot de 'zeer bijzondere omstandigheden' kan worden gerekend op grond waarvan de Hoge Raad een doorbreking van de geheimhoudingsplicht gerechtvaardigd acht. Wij zijn van mening dat dit niet het geval is en dat de Hoge Raad in het genoemde opsporingsbelang een buitenwettelijke rechtvaardigingsgrond heeft gecreëerd die in strijd is met het wettelijk systeem en met de uitdrukkelijke bedoeling van de wetgever.

2

DE ZAAK

Het betreft in het arrest van de Hoge Raad een beklag als bedoeld in artikel $552 \mathrm{a} \mathrm{Sv}$ tegen inbeslagneming van patiënten- en personeelsbestanden van een psychiatrische inrichting voor jeugdigen, verder te noemen de Stichting. De bestanden waren in beslag genomen vanwege het vermoeden dat een zestal jaren tevoren seksuele delicten door een veertienjarige bewoner zouden zijn gepleegd tegen een elfjarige medebewoner van de inrichting. Tegen de veertienjarige was aangifte gedaan door de ouders van de elfjarige. Het doel van de inbeslagneming was het achterhalen van de naam van de verdachte. De inbeslaggenomen gegevens waren aan de rechter-commissaris (R-C) afgegeven in een gesloten envelop. Op deze manier kon eerst het oordeel van de rechter over de rechtmatigheid van de inbeslagneming worden afgewacht alvorens de gegevens via politie en justitie openbaar zouden worden.

Om vast te stellen of de speciale regelingen van het Wetboek van Strafvordering voor verschoningsgerechtigden van toepassing zijn, is de vraag van belang wie zich in deze casus op het verschoningsrecht kan beroepen. De discussie over die vraag wordt in het arrest van de Hoge Raad nauwelijks gevoerd. De advocaat-generaal (A-G) is van mening dat de directeur van de Stichting, tevens psychiater, verschoningsgerechtigde is. Daarna stelt de A-G vast dat aan de Stichting een afgeleid verschoningsrecht toekomt. De Hoge Raad volgt dezelfde werkwijze en komt tot dezelfde conclusie.

Om te kunnen spreken van verschoningsrecht moet er een persoon zijn die een beroepsgeheim heeft. In principe is de behandelend arts/psychiater geheimhouder. Algemeen is aanvaard dat behandelend artsen een verschoningsrecht toekomt. De Stichting (of het ziekenhuis dan wel de instelling) heeft een afgeleid verschoningsrecht. De directeur heeft in het algemeen ook een afgeleid verschoningsrecht omdat hij in dienst is van de instelling. Slechts indien een directeur tevens arts/psychiater is, heeft hij een zelfstandig verschoningsrecht. 
Brieven en geschriften die onder het verschoningsrecht vallen zijn op grond van artikel $98 \mathrm{~Sv}$ uitgesloten van inbeslagneming. ${ }^{5}$ De inbeslagneming betrof in casu patiëntengegevens en personeelsgegevens. ${ }^{6}$ In principe bepaalt de verschoningsgerechtigde zelf wat onder het verschoningsrecht valt. ${ }^{7}$ Als regel bepaalt de verschoningsgerechtigde ook zelf of hij gegevens, die onder het verschoningsrecht vallen, vrij wil geven. ${ }^{8}$ In dat verband bestaan er drie mogelijkheden; openbaarmaking van het geheim is toegestaan: I. bij toestemming van de patiënt, 2. op grond van een wettelijke plicht en 3. op grond van een (buitenwettelijk genormeerd) conflict van plichten.

De keuze van de medisch hulpverlener om zich op zijn beroepsgeheim te beroepen kan in rechte, zij het marginaal, worden getoetst. Die toets houdt in dat de keuze van de medisch geheimhouder in beginsel wordt gerespecteerd 'tenzij redelijkerwijs geen twijfel erover kan bestaan dat dit standpunt onjuist is;'” bijvoorbeeld omdat duidelijk is dat de verschoningsgerechtigde zich op oneigenlijke gronden (zoals het maskeren van eigen strafbare feiten) op zijn plicht tot geheimhouding beroept.

\section{I Patiëntengegevens: de visie van A-G Machielse}

Bij de conclusie van de A-G plaatsen wij, vanwege het belang van zijn betoog, enkele kanttekeningen. De eerste kanttekening betreft de stelling van Machielse dat NAWgegevens ${ }^{\mathrm{TO}}$ niet altijd onder het verschoningsrecht hoeven te vallen. Voorwaarde voor een geslaagd beroep op het verschoningsrecht is naar zijn mening dat er een verband bestaat tussen het gepleegde delict en het beroep op het verschoningsrecht. Dit zou betekenen dat bijvoorbeeld degene die als bolletjesslikker in een ziekenhuis binnenkomt wat het drugsdelict betreft beschermd wordt door het verschoningsrecht. De toegankelijkheid van de zorg en de privacy van de patiënt zijn immers in het geding en er is een direct verband tussen het gepleegde delict en de vraag om medische zorg. Indien dezelfde bolletjesslikker door de politie wordt gezocht voor een door hem gepleegde moord zouden de NAW-gegevens niet onder het verschoningsrecht vallen, aangezien een direct verband tussen het delict en het verzoek om zorg ontbreekt.

Deze redenering vinden wij om twee redenen te beperkt. Ten eerste zou de bolletjesslikker mogelijk geen medische hulp zoeken voor het 'bolletjesprobleem' als hij zou weten dat de arts zijn gegevens wel vrij zou geven voor een ander strafrechtelijk doel. Ten tweede kan hulp geboden zijn ook in die gevallen waarin een direct verband

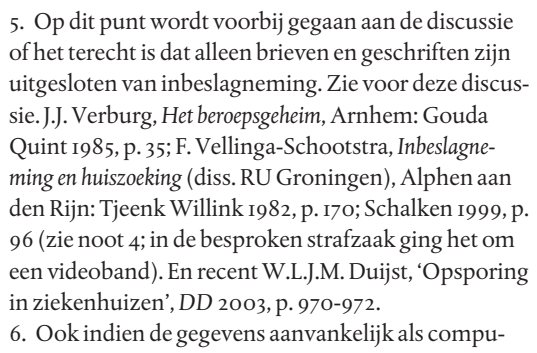

5. Op dit punt wordt voorbij gegaan aan de discussie of het terecht is dat alleen brieven en geschriften zijn uitgesloten van inbeslagneming. Zie voor deze discussie.J.J. Verburg, Het beroepsgeheim, Arnhem: Gouda Quint 1985, p. 35; F. Vellinga-Schootstra, Inbeslagneming en huiszoeking (diss. RU Groningen), Alphen aan den Rijn: Tjeenk Willink 1982, p. I70; Schalken 1999, p. 96 (zie noot 4; in de besproken strafzaak ging het om een videoband). En recent W.L.J.M. Duijst, 'Opsporing in ziekenhuizen', DD 2003, p. 970-972. 6. Ook indien de gegevens aanvankelijk als compu-

terbestand waren opgeslagen, worden deze bestanden gezien als geschriften, zie HR I5 januari I99I, NJ I99I, 668.

7. Zie onder andere HR 30 november I999, NJ 2002, 438 (m.nt. YB) en HR I2 februari 2002, NJ 2002, 440 (m.nt. YB).

8. Zie H.J.J. Leenen, Handboek Gezondheidsrecht, deel I, Houten/Diegem: Bohn Stafleu van Loghum 2002, p. 234 .

9. HR 22 november I99I, NJ I992, 3 I5.

Io. NAW staat voor naam, adres en woonplaats. 
tussen het gepleegde strafbare feit en de gezochte medische hulp ontbreekt. Zo ontbreekt bij een in Nederland verblijvende illegaal het verband tussen de strafbare feiten die voortvloeien uit het illegale verblijf en de vereiste medische hulp vaak geheel en al. De toegankelijkheid van de zorg is echter wel in het geding.

In de voorbeelden die door Machielse genoemd worden lijkt de bescherming van NAW-gegevens alleen te gelden indien de verdachte in relatie tot zijn delict medische hulp zoekt. Echter ook wanneer een slachtoffer van een delict medische hulp zoekt kan de toegankelijkheid van de zorg in het geding zijn. Te denken valt aan slachtoffers van thuisgeweld (zo 'huiselijk' is dit geweld niet). Het slachtoffer heeft geen enkel vergrijp gepleegd, maar zou zich in bepaalde gevallen niet tot een hulpverlener wenden indien het verschoningsrecht zich niet zou uitstrekken tot de NAW-gegevens van de patiënt (gegevens die immers ook interessant zijn voor een 'boze' echtgenoot of vader).

Voor de beslissing of NAW-gegevens al dan niet onder het verschoningsrecht vallen moet dan ook alleen het algemeen belang inzake de toegankelijkheid van de zorg als leidraad dienen. Een direct verband tussen het strafbare feit en de vereiste medische hulp kan een goede reden zijn om de gegevens niet vrij te geven (in het kader van de hierna te bespreken belangenafweging), maar kan zeker niet de enige reden zijn.

Bovendien kan nog een kanttekening worden geplaatst bij de stelling van Machielse dat er in casu geen aanwijzingen waren dat de jongens (althans de verdachte) waren opgenomen voor seksueel afwijkend gedrag. Dit is een stelling die niet onderbouwd kan worden tenzij de verschoningsgerechtigde zich hierover uitlaat en dus zijn beroepsgeheim openbreekt. Er kan geen twijfel over bestaan dat gegevens over de reden van de opname zeker onder het verschoningsrecht vallen.

Het voorgaande neemt niet weg dat Machielse een op zichzelf verdienstelijke poging heeft gedaan om het belang van de geheimhouding nader te concretiseren. Belangen die almaar in abstracto fungeren in een belangenafweging, zijn vaak moeilijk op hun onderlinge gewicht te beoordelen. Daarom is het jammer dat de Hoge Raad daarover niets zegt. In plaats daarvan heeft hij een ander abstract belang geformuleerd dat een doorbreking van de geheimhoudingsplicht moet rechtvaardigen (zie sub 7). In casu rangschikte de Hoge Raad de NAW-gegevens wel onder het verschoningsrecht, maar oordeelde hij een inbreuk op dat recht aanvaardbaar vanwege een hoger (opsporings)belang.

\subsection{Personeelsbestanden}

De Hoge Raad komt tot de conclusie dat personeelsgegevens niet onder het verschoningsrecht vallen. De inbeslagneming van personeelsgegevens laten wij in het kader van dit artikel onbesproken; wij vermelden slechts dat inbeslagneming van personeelsgegevens mogelijk is, daar deze gegevens niet onder het verschoningsrecht vallen.

Dan nu de kern van het arrest van de Hoge Raad: als eenmaal vaststaat wie verschoningsgerechtigde is en wat onder het verschoningsrecht valt, komt de vraag aan de orde of openbaarmaking van het geheim wellicht door een hoger belang kan worden 
gerechtvaardigd. De Hoge Raad heeft 'onder zeer bijzondere omstandigheden' het belang van de waarheidsvinding als een belang van nog hogere orde aangemerkt. ${ }^{\text {II }}$ In HR 30 november 1999, NJ 2002, 438, waarin het ging om een advocaat die verdacht werd van een ernstig strafbaar feit, formuleert de Hoge Raad het als volgt. 'De beantwoording van de vraag welke omstandigheden als zeer uitzonderlijk worden aangemerkt laat zich niet in algemene regels vatten. De enkele omstandigheid dat een advocaat als verdachte wordt aangemerkt, is in ieder geval niet toereikend om zijn verschoningsrecht te verbreken. Dat kan anders zijn bij verdenking van een ernstig strafbaar feit, zoals het vormen van een crimineel samenwerkingsverband van een advocaat met bepaalde cliënten. Dan zal het belang van die cliënten dat zij ervan moeten kunnen uitgaan dat de advocaat geheim houdt hetgeen zij hem in die criminele aangelegenheid hebben toevertrouwd moeten wijken voor het belang dat de waarheid aan het licht komt. In een dergelijk geval dienen het verschoningsrecht en de daarmee samenhangende beperkingen van de uitoefening van de beslag- en huiszoekingsbevoegdheden te wijken voor het belang van de strafvordering.' ${ }^{\text {I2 }}$

Wat kan uit deze, zo langzamerhand standaard geworden, ${ }^{13}$ redenering van de Hoge Raad geconcludeerd worden? Het verschoningsrecht is belangrijk, maar niet absoluut. Onder zeer uitzonderlijke omstandigheden moet het verschoningsrecht plaats maken voor het belang van de opsporing. Of zich zeer uitzonderlijke gevallen voordoen moet per geval worden beoordeeld. Totnogtoe was er volgens de Hoge Raad alleen sprake van zeer uitzonderlijke gevallen, indien de verschoningsgerechtigde zelf verdachte was van een ernstig strafbaar feit. ${ }^{\mathrm{I}}$

De rechtspraak komt doorgaans langs twee wegen tot de conclusie dat het opsporingsbelang prevaleert: of door vast te stellen dat het verschoningsrecht zich niet uitstrekte tot de gegevens die in beslag genomen moesten worden, of door vast te stellen dat de gegevens onderwerp waren van een strafbaar feit. ${ }^{15}$ Door enkele rechtbanken zijn ook zeer uitzonderlijke omstandigheden aangenomen, indien de patiënt verdachte was van een ernstig strafbaar feit. ${ }^{16}$ Als argumenten voor het laten prevaleren van het opsporingsbelang worden door deze rechtbanken genoemd het ontbre-

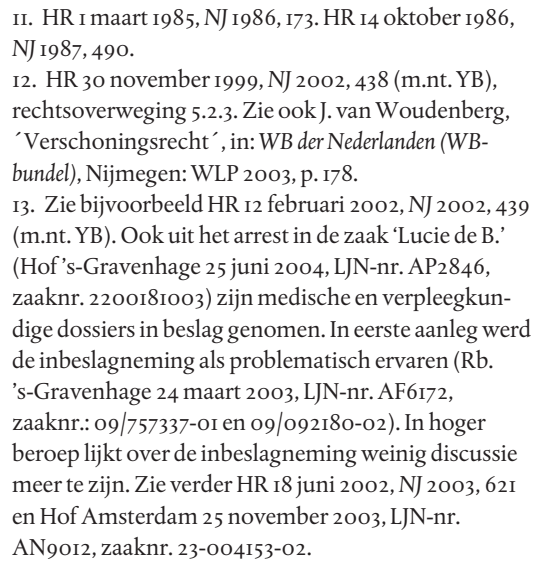

I4. HR I maart I985, NJ I986, I73; HR I4 oktober I986, NJ I987, 490; HR 30 november I999, NJ 2002, 438; HR I2 februari 2002, NJ 2002, 439 (m.nt. YB); Hof Amsterdam 25 november 2003, LJN-nr. AN9oI2, zaaknr. 23-Oo4I53-O2; HR 25 september 20oI, LJN-nr. AB328o, zaaknr. 03022/oo B.

I5. Hof Amsterdam 2r december 1989, NJ I990, 805; $\mathrm{HR}_{3}$ juli 20OI, NJ 2002, 8.

I6. Rb. Amsterdam 9 augustus I996, TvGR I997/46 en $M C$ 1996, p. II33-II34 (betrof een overlijden na een overdosis drugs); Rb. Zwolle 4 december I998, TvGR I999/20 (ouders verdacht van Münchhausen by proxy); Rb. 's-Gravenhage 28 oktober 2003, parketnr. RK 03/655, niet gepubliceerd (zedendelict). 
ken van ander bewijs, ${ }^{17}$ de ernst van het delict (levensdelict/zedendelict), ${ }^{18}$ een maatschappelijk belang, ${ }^{19}$ de weerloosheid van het slachtoffer (kind ${ }^{20}$ en de geschokte rechtsorde. ${ }^{21}$

Verschillende rechtbanken zijn aldus de 'zeer uitzonderlijke omstandigheden' ruimer gaan uitleggen dan in de literatuur over het algemeen wordt aangenomen. Door verscheidene auteurs is er een directe relatie gelegd tussen de ernst van het strafbare feit en de dreiging die daarvan voor de veiligheid of het leven van anderen uitgaat. ${ }^{22}$ Dit impliceert dat het strafbare feit in zijn uitwerking nog actueel en de gevolgen nog acuut moeten zijn, d.w.z. dat het misdrijf nog steeds bedreigende consequenties moet hebben voor een bepaald persoon of voor zijn omgeving. Pas als door ingrijpen van het strafrecht die gevolgen ongedaan kunnen worden gemaakt, is er reden het belang van de opsporing voorrang te geven boven het belang dat met het medisch beroepsgeheim is gemoeid. ${ }^{23}$

Vastgesteld moet worden dat de Hoge Raad zelf dat vereiste van acuutheid nimmer expliciet als criterium heeft geformuleerd. Blijkens de uitspraak van 29 juni 2004 heeft de Hoge Raad, in elk geval in die zaak, van dat criterium afstand genomen. Ook als het vermoedelijke strafbare feit vroeger heeft plaatsgevonden en de opsporing slechts de opheldering daarvan dient (dus niet het wegnemen van actuele dreigingen), ziet de Hoge Raad reden om het opsporingsbelang een groter gewicht toe te kennen dan het belang van de geheimhouding.

De Hoge Raad volgt in zijn arrest de redenering van de Haagse rechtbank. In de afweging van belangen zijn, aldus het arrest, de volgende factoren van belang: de aard van de gevraagde gegevens, de omstandigheid dat de gegevens niet op een andere manier te verkrijgen zijn en het feit dat het een ernstig delict, begaan in de instelling waar het slachtoffer verbleef, betreft. ${ }^{24} \mathrm{Het}$ slachtoffer heeft recht op bescherming door de instelling tegen seksuele intimidatie. Het slachtoffer heeft tevens recht op strafrechtelijke bescherming voor tegen hem gepleegde delicten. Dit recht op bescherming brengt met zich dat het slachtoffer recht heeft op een strafrechtelijk onderzoek betreffende de tegen hem gepleegde delicten.

Bij de afweging of het verschoningsrecht moet prevaleren boven het belang van de waarheidsvinding, is voor de Hoge Raad met name van belang dat de uitoefening van het verschoningsrecht in de onderhavige zaak afbreuk kan doen aan het maatschappelijk belang van ouders die zich vrijelijk en zonder vrees voor het wegvallen van de bescherming van hun kind, om bijstand en advies tot een arts moeten kunnen wenden

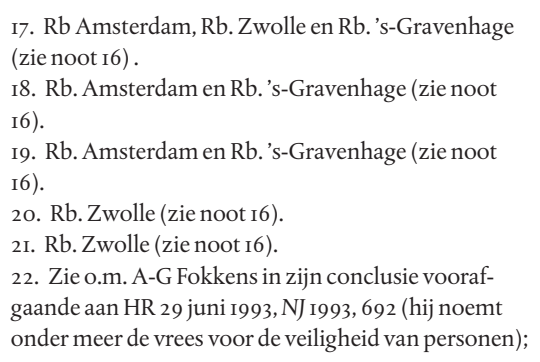

Schalken I999, p. Ioo (zie noot 4; Schalken spreekt over een acuut strafrechtelijk belang); Leenen 2002, p. 234 (zie noot 8); en H.J.C. van Marle, 'Het voorspellen van gevaar en de geheimhouding van de behandelaar', Trema I998, p. IOO-IO3. 23. Schalken I999, p. Ioo (zie noot 4). 24. De argumenten werden in het verleden ook al door andere rechtbanken genoemd. Zie de eerder genoemde uitspraken van de Rechtbanken Zwolle en Amsterdam (zie noot I6). 
teneinde hun kind als patiënt in een centrum als het onderhavige te laten opnemen. Tegen die achtergrond kent de Hoge Raad meer gewicht toe aan de opheldering van het strafbare feit dan aan het belang dat met het verschoningsrecht wordt gediend.

Het argument dat de rechtbank aanvoert en door de Hoge Raad wordt overgenomen is dat de ouders ervan uit moeten kunnen gaan dat hun kind de bescherming krijgt van de arts (en instelling) aan wiens zorg hun kind is toevertrouwd. Dit deel van de redenering staat (uiteraard) niet ter discussie. De ouders mogen inderdaad verwachten dat hun kind binnen de instelling waar het verblijft wordt gevrijwaard van seksueel misbruik. Maar niet de arts of de instelling staat terecht in deze zaak. Er vindt hier geen vervolging plaats op grond van artikel $255 \mathrm{Sr}$ (geen zorg voor hulpbehoevende).

Met de Hoge Raad zijn wij van mening dat de toegankelijkheid van de zorg wordt belemmerd, indien de veiligheid van patiënten in een instelling niet gegarandeerd wordt. Maar het al dan niet voldoende bescherming bieden aan patiënten staat in dit geval los van het verschoningsrecht. Het verschoningsrecht heeft als doel het garanderen van de individuele privacy van de patiënt en de toegankelijkheid van de zorg voor een ieder. Het argument betreffende de toegankelijkheid van de zorg - délegitimatie van het verschoningsrecht - wordt nu door de Hoge Raad aangewend om een gerechtvaardigd beroep op datzelfde verschoningsrecht opzij te zetten. Dit recht, zo zegt de Hoge Raad, mag niet zo worden gebruikt dat de ouders van kinderen zich door de uitoefening van het verschoningsrecht niet meer vrij voelen om de hulp van een arts in te roepen. De Hoge Raad lijkt ervan uit te gaan dat de toegankelijkheid van de zorg gediend wordt door de wetenschap dat de verschoningsgerechtigde zijn beroepsgeheim doorbreekt indien hij een strafbaar feit constateert. Het merkwaardige is dat patiënten en ouders van patiënten er juist niet van uit mochten gaan dat de verschoningsgerechtigde aangifte zou doen van een strafbaar feit of een strafbaar feit dat stond te gebeuren zouden melden. Van beide plichten zijn verschoningsgerechtigden in respectievelijk artikel I6o lid 2 Sv en artikel 137 Sr uitdrukkelijk vrijgesteld.

Wat is de betekenis van de redenering van de Hoge Raad? Hoewel het Wetboek van Strafvordering duidelijk het door het verschoningsrecht gediende belang laat prevaleren boven het belang van de opsporing van strafbare feiten, neemt de Hoge Raad aan dat er voor een hulpverlener een maatschappelijke plicht bestaat om de politie en het openbaar ministerie in bepaalde gevallen informatie te verschaffen die valt onder het verschoningsrecht.

Deze visie is vergelijkbaar met de redenering in een recent vonnis van de Rechtbank Assen in een civiele zaak. ${ }^{25}$ Het betrof een psychotherapeut die in het kader van

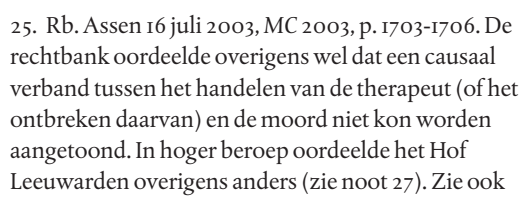

25. Rb. Assen I6 juli 2003, MC 2003, p. 1703-1706. De rechtbank oordeelde overigens wel dat een causaal verband tussen het handelen van de therapeut (of het ontbreken daarvan) en de moord niet kon worden aangetoond. In hoger beroep oordeelde het Hof Leeuwarden overigens anders (zie noot 27). Zie ook

CT I6 november 200o, MC 20oi, p. 429-430. Het Centraal Tuchtcollege was van mening dat een huisarts de familie had moeten waarschuwen over de besmettelijkheid van een ziekte. Dit leidde echter niet tot een tuchtrechtelijke maatregel. 
therapie van zijn cliënt te horen kreeg dat hij iemand zou gaan vermoorden. Toen daadwerkelijk een moord werd gepleegd, weliswaar op een ander, oordeelde de rechtbank dat de therapeut ten onrechte zijn beroepsgeheim niet geschonden had. De rechtbank stelde een maatschappelijke plicht vast, ${ }^{26}$ terwijl artikel $137 \mathrm{Sr}$ de verschoningsgerechtigde uitdrukkelijk vrijstelt van de plicht tot het melden van 'toekomstige' delicten. Het vaststellen van een dergelijke maatschappelijke plicht door de civiele rechter is naar onze opvatting strijdig met het uitgangspunt van de wetgever om het beroepsgeheim te laten prevaleren boven het belang van de opsporing. Als die maatschappelijke plicht in een civiele zaak ten aanzien van een toekomstig delict niet kan worden aangenomen, is dat zeker het geval in een strafzaak waarin het gaat om de opsporing van een vermoedelijk gepleegd strafbaar feit uit het verleden. ${ }^{27}$

Wanneer een verschoningsgerechtigde kennis krijgt van een strafbaar feit, dient onderscheid gemaakt te worden naar het moment waarop er van een strafbaar feit sprake is. Als het delict heeft plaatsgevonden en er geen gevaar (meer) voor de omgeving te duchten valt, behoort het belang van de geheimhouding te prevaleren omdat de onthulling van het geheim in die situatie slechts de opsporing kan dienen, terwijl dat doel door de wetgever niet als een (zelfstandige) reden is erkend voor doorbreking van het beroepsgeheim. Wij verwijzen ook naar de Leidse balpen-zaak, waarin de therapeute aangifte deed van een moord die (volgens haar cliënt) reeds was gepleegd en zij om die reden door het College van Beroep NIP in 1997 werd veroordeeld. ${ }^{28}$

De situatie kan anders komen te liggen bij een voorgenomen misdrijf of bij een misdrijf dat voltooid is terwijl er risico op herhaling bestaat. Als een verschoningsgerechtigde kennis draagt van het voornemen tot een misdrijf, is hij weliswaar niet verplicht daarvan aangifte te doen, maar hij kan wel, indien er zeer concrete aanwijzingen zijn dat het misdrijf dreigt te worden uitgevoerd, in een conflict van plichten terechtkomen waarvan de gerechtvaardigde uitkomst kan zijn dat het geheim wordt onthuld. Wat tijdens een therapie allemaal aan (slechte) intenties te berde wordt gebracht, zal niet snel, zo al ooit, reden kunnen zijn de politie in te schakelen. Een arts echter die in een individueel geval serieus weet heeft van kindermishandeling, zal zich niet altijd achter zijn beroepsgeheim kunnen verschuilen. ${ }^{29}$ Hoewel het doorbreken van het beroepsgeheim door de wetgever recent ${ }^{30}$ vooral als een recht van de hulpverlener is geformuleerd, zou men zelfs kunnen verdedigen dat die hulpverlener, naar gelang de ernst en de acuutheid van de situatie, een plicht heeft iets te ondernemen (art. $255 \mathrm{Sr}$, onthouden van noodzakelijke hulp), ook al schendt hij daarmee de vertrouwelijkheid van de arts-patiënt-relatie.

Maar ook dan past de verschoningsgerechtigde terughoudendheid. Bij een toegestane overschrijding van de grenzen van het beroepsgeheim spelen de beginselen van subsidiariteit en proportionaliteit een voorname rol, d.w.z. dat de arts de voorkeur

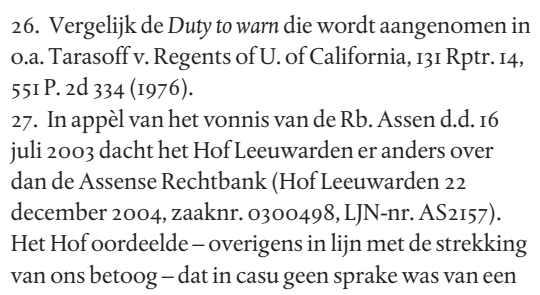

acuut dreigend gevaar en dat er geen grond bestond om het beroepsgeheim te doorbreken.

28. Col. Beroep NIP 20 juni I997, TvGR I999/43.

29. CMT 28 september $1972, N^{1}$ 1973, 270.

30. Zie art. II van de Wet op de jeugdzorg (Stb. 2004, 306) die de Wet op de jeugdhulpverlening heeft vervangen (in de art. $34 \mathrm{c}$ en $34 \mathrm{~d}$ van die wet was een regeling opgenomen in verband met de advies- en meldpunten kindermishandeling; Stb. 2002, 5I5). 
moet geven aan inschakeling van die instanties die aan een oplossing van het dreigende acute gevaar het beste kunnen bijdragen (soms is dat de politie, maar soms ook niet, zoals bij kinderbescherming) en dat de arts niet meer aan de openbaarheid mag prijsgeven dan voor het weren van het gevaar noodzakelijk is. ${ }^{31}$

Indien er al gronden zouden zijn om het verschoningsrecht wegens een gepleegd misdrijf niet uit te oefenen, geldt altijd nog het algemene vereiste dat het niet alleen om een ernstig misdrijf moet gaan, maar vooral ook om een ernstige verdenking dat zo'n misdrijf is begaan. Een enkele aangifte kan weliswaar voldoende verdenking opleveren om een strafrechtelijk onderzoek te rechtvaardigen, maar wanneer de verdenking als argument wordt gebruikt om het medisch beroepsgeheim te doorbreken zal de aangifte zeer ernstige aanwijzingen moeten bevatten dat het beweerdelijke misdrijf ook daadwerkelijk heeft plaatsgevonden en dat de genoemde personen op basis van objectiveerbare feiten en omstandigheden als verdachten van dat misdrijf kunnen worden aangemerkt. ${ }^{32}$ Het requisitoir van de officier van justitie in de onderhavige strafzaak bevatte onvoldoende informatie om het niveau van de verdenking te kunnen beoordelen. Als het voorgenomen strafrechtelijke onderzoek en dus het terzijde stellen van het beroepsgeheim bedoeld is om de verlangde aanwijzingen boven het niveau van het redelijk schuldvermoeden ex artikel $27 \mathrm{~Sv}$ te tillen, is dat de verkeerde volgorde.

Bovendien zal bij de beoordeling van de opportuniteit van een eventueel in te stellen onderzoek en een daarop te baseren vervolging in het bijzonder moeten meewegen of inschakeling van het strafrecht wel de meest adequate interventie oplevert. Vaak wordt door het middel van het strafrecht meer kapot gemaakt dan toch al is geschied. Als er intern (zoals in de onderhavige casus) en beleidsmatig aandacht is besteed aan het betreffende voorval van eventuele seksuele misdragingen, kan dat veel effectiever zijn. Na zes jaar lijkt het strafrecht niet meer te kunnen bieden (als het voorval al kan worden opgehelderd) dan wat mosterd na de maaltijd die over de consumptiedatum heen is. En welke schade is er dan weer opnieuw aangericht? Wordt het strafrecht hier niet overvraagd?

Het spreekt voor zich dat met de opheldering van ernstige strafbare feiten, zoals de Hoge Raad nogmaals vaststelt, een serieus maatschappelijk belang is gemoeid. Het probleem is echter dat de wetgever dit belang ondergeschikt heeft gemaakt aan een ander belang dat gediend wordt met het bewaren van een specifiek beroepsgeheim. De Hoge Raad gaat met het buiten de wet om opwaarderen van het maatschappelijk belang van de opsporing direct in tegen de intentie van de wetgever die uiteraard de reguliere opheldering van ernstige strafbare feiten destijds heeft gewogen tegen andere belangen, maar voor het maatschappelijk belang van de opsporing toch geen uitzondering heeft willen maken.

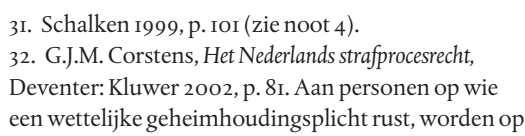


Die afweging op wetgevingsniveau heeft geresulteerd in een wettelijk systeem dat dicteert onder welke omstandigheden inbeslagneming van brieven of geschriften bij verschoningsgerechtigden mogelijk is (art. $98 \mathrm{~Sv}$ ). Inbeslagneming is slechts mogelijk indien de persoon in kwestie geen verschoningsrecht toekomt, indien de gegevens niet kunnen worden gekwalificeerd als geschriften, indien de geschriften niet onder het verschoningsrecht vallen of indien zij voorwerp zijn van een strafbaar feit of tot het begaan daarvan gediend hebben.

In de hier aan de orde zijnde strafzaak is er sprake van een verschoningsgerechtigde, de geschriften vallen in de ogen van de Hoge Raad onder het verschoningsrecht, zijn geen voorwerp van een strafbaar feit en hebben niet tot het begaan daarvan gediend. Desalniettemin neemt de Hoge Raad aan dat er een bevoegdheid bestaat om de geheim te houden gegevens in beslag te nemen, omdat de opsporing van een (ernstig, maar oud en moeilijk te ontrafelen) strafbaar feit kennelijk tot de 'zeer uitzonderlijke omstandigheden' moet worden gerekend. Wat is daar nu zo bijzonder aan dat de wetgever dat destijds niet heeft voorzien? Door de bevoegdheid tot inbeslagneming op deze wijze uit te breiden creëert de Hoge Raad een bevoegdheid die geen basis heeft in de wet en zelfs met het wettelijk systeem in strijd is. Van de enige uitzondering die de Hoge Raad tot nu toe heeft aanvaard (de verschoningsgerechtigde was zelf verdachte), kan tenminste nog worden gezegd dat zij bij de ratio van het wettelijk systeem aansluit (vgl. de gegevens die onderdeel uitmaken van het strafbare feit). Dan komen we wel in de buurt van misbruik van recht.

De door rechtbanken en sinds kort door de Hoge Raad aangevoerde argumenten met betrekking tot de ernst van het gepleegde delict, het maatschappelijke belang dat met de opsporing daarvan gediend moet worden, de belangen van het slachtoffer en de (on)mogelijkheid om de gegevens langs strafvorderlijke weg te verkrijgen zijn overwegingen die thuishoren bij de proportionaliteits- en subsidiariteitstoets. Deze toets komt doorgaans pas in beeld als de formele vraag naar de wettelijke bevoegdheid tot inbeslagneming positief is beantwoord.

Dit alles neemt niet weg dat er bijzondere omstandigheden kunnen zijn die doorbreking van het medisch beroepsgeheim rechtvaardigen. Maar dan spreken we over een situatie die sterk aan de casuïstiek is gekoppeld, waarin de geheimhouder zich bevindt in een conflict van plichten (bewaken van het beroepsgeheim versus het afwenden van dreigend gevaar) dat hem dwingt tot een keuze tussen naleving van met elkaar strijdige (maatschappelijke) plichten, welke keuze binnen de wettelijke grenzen principieel is voorbehouden aan de geheimhouder zelf. Bij de in dat verband te maken afweging hoeft de geheimhouder geen rekening te houden met de algemene burgerlijke plicht om in bepaalde gevallen mee te werken aan de opheldering van strafbare feiten, kan hij zelfs verwijtbaar handelen als hij dit zonder heel goede redenen toch doet.

Wat de Hoge Raad nu heeft gedaan is opmerkelijk. Door het formuleren van een buitenwettelijke grond voor inbeslagneming bij geheimhouders voert de Hoge Raad het belang van de opsporing op als een nieuw belang in de afweging van belangen terwijl de wetgever die afweging reeds heeft gemaakt. In die nieuwe afweging - die niet meer is gekoppeld aan de beoordelingsruimte van de verschoningsgerechtigde in het kader van een conflict van plichten - formuleert de Hoge Raad de opsporing als een algemeen, abstract en niet gedifferentieerd hoger belang dat aan de kant van poli- 
tie en justitie vertaald wordt als een bevoegdheid om een wettelijk nauw omschreven waarborg terzijde te stellen en dit bovendien zonder een duidelijke grens aan te geven. Want wanneer is de opheldering van ernstige strafbare feiten niet ernstig genoeg meer om het beroepsgeheim niet te negeren?

Hoe begrijpelijk de zienswijze van de Hoge Raad op het eerste oog wellicht ook moge zijn (bescherming van kinderen in een extra afhankelijke positie), het arrest is bij nadere analyse bepaald geen aanwinst voor de jurisprudentiële ontwikkeling van het beroepsgeheim en het recht zich op basis daarvan te verschonen. 